\title{
Pengaruh Terapi Relaksasi Progresif Terhadap Kadar Gula Darah Pasien Diabetes Mellitus Tipe 2
}

\author{
Wahyuningsih Safitri $^{{ }^{*}}$, Rahajeng Putriningrum ${ }^{2}$ \\ ${ }^{1}$ Program Studi Sarjana Keperawatan, STIKes Kusuma Husada Surakarta \\ ${ }^{2}$ Program Studi D3 Kebidanan, STIKes Kusuma Husada Surakarta \\ *Email: wahyuningsihsafitri@gmail.com
}

\begin{abstract}
Kata Kunci
Abstrak

Terapi

Relaksasi

Progresif,

Kadar Gula

Darah,

Diabetes

Mellitus

Pencegahan penting dilakukan oleh penderita diabetes melitus agar tidak terjadi komplikasi dan kematian. Salah satu cara yang bisa dilakukan oleh penderita dengan mengontrol kadar gula darah tetap stabil dan tidak melebihi batas normal yaitu dengan terapi relaksasi progresif. Tujuan dalam penelitian ini untuk mengetahui pengaruh terapi relaksasi progresif terhadap kadar gula darah pasien diabetes mellitus tipe 2. Penelitian ini merupakan penelitian dengan pendekatan quasi eksperimen dengan rancangan one group pre and post test design. Populasinya adalah seluruh pasien, diambil sampel 18 responden dengan teknik purposive sampling. Analisis dengan uji paired simple t test. Hasil penelitian menunjukkan kadar gula darah sebelum perlakuan didapatkan rata-rata sebesar 173,07 mg/dL; Hasil pengukuran kadar gula darah sesudah perlakuan didapatkan data rata-rata sebesar $161,68 \mathrm{mg} / \mathrm{dL}$. Kesimpulan dalam penelitian ini adalah ada pengaruh signifikan terapi relaksasi progresif terhadap kadar gula darah penderita diabetes mellitus tipe 2 ( $p$ value $=0,001$.
\end{abstract}

\section{The Effects of Progerssive Relaxation Therapy on Blood Sugar Levels of Patients Diabetes Mellitus Type 2}

\begin{abstract}
Key Words: $\quad$ Abstract
Progressive Prevention is important for people with diabetes mellitus to avoid complications and Relaxation death. One way that can be done by patients by controlling blood sugar levels Therapy, Sugar Blood Level,

Diabetes

Mellitus remains stable and does not exceed normal limits, namely by progressive relaxation therapy. The purpose of this study was to determine the effect of progressive relaxation therapy on blood sugar levels of patients with type 2 diabetes mellitus. This study was a quasi-experimental approach with the design of one group pre and post test design. The population was all patients, taken a sample of 18 respondents with purposive sampling technique. Analysis was done by paired simple t test. The results showed that blood sugar levels before treatment obtained an average of $173.07 \mathrm{mg} / \mathrm{dL}$; The results of measurement of blood sugar levels after treatment obtained an average data of $161.68 \mathrm{mg} / \mathrm{dL}$. The conclusion in this study is that there is a significant effect of progressive relaxation therapy on blood sugar levels of people with type 2 diabetes mellitus ( $p$-value $=0.001$ ).
\end{abstract}


PROFESI (Profesional Islam): Media Publikasi Penelitian

2019; Volume 16; No 2.

Website: ejournal.stikespku.ac.id

\section{PENDAHULUAN}

Diabetes Melitus merupakan kumpulan gejala pada seseorang yang disebabkan adanya peningkatan kadar glukosa darah akibat penurunan sekresi insulin yang progresif oleh resistensi insulin (Soegondo, 2011). Keadaan ini ditandai dengan ketidakrentanan /ketidakmampuan organ menggunakan insulin, sehingga insulin tidak bisa berfungsi optimal dalam mengatur metabolisme glukosa. Akibatnya, kadar glukosa darah meningkat (hiperglikemi). Karakteristik hiperglikemi selain karena kelainan sekresi insulin juga dapat terjadi karena insulin tidak bekerja atau duaduanya (Bustan, 2007).

Hiperglikemi ditandai dengan kadar gula darah sewaktu lebih dari $11,1 \mathrm{mmol} / \mathrm{l}$ (> 200 $\mathrm{mg} / \mathrm{dl}$ ) (WHO, 2012). Peningkatan kadar gula darah pada pasien diabetes mellitus berkaitan dengan stress. Kondisi stress dengan penderita diabetes mellitus berhubungan sangat erat. Stres adalah suatu kondisi dimana kebutuhan tubuh tidak terpenuhi secara adekuat, sehingga akan berakibat terjadinya gangguan keseimbangan. Stress mengaktifkan sistem neuroendokrin dan sistem saraf simpatis melalui hipotalamus pituitari-adrenal sehingga menyebabkan pelepasan hormon-hormon misal epinefrin, tiroid, kortisol, dan glukagon yang dapat mempengaruhi kadar gula darah (Hasaini, 2015).

Stress merupakan salah satu faktor terjadinya hiperglikemia pada pasien DM tipe 2. Kondisi stress yang dialami pasien mengakibatkan kadar gula darah meningkat. Hal ini disebabkan oleh pengeluaran epinefrin. Epinefrin menghambat sekresi insulin, memacu pelepasan glukagon, mengaktivasi pemecahan glikogen dan mengganggu kerja insulin pada jaringan baik otot maupun jaringan adiposa serta hepar sehingga produksi gula hati meningkat dan kapasitas mengatur beban gula eksogen terganggu (Sudoyo dkk, 2009).

Jenis diabetes melitus meliputi diabetes melitus tipe 1 , diabetes melitus tipe 2, diabetes melitus gestasional dan diabetes melitus tipe lain. Menurut jenis dan etiologinya, jenis diabetes mellitus yang terbanyak di Indonesia adalah DM tipe 2 yaitu $90 \%$ dari seluruh populasi DM, mayoritas terjadi pada orang dewasa dengan usia lebih dari 30 tahun (Lingga, 2012). Diabetes mellitus tipe 2 disebabkan kurangnya respon jaringan dari otot, jaringan adiposa dan hepar terhadap insulin. Pasien dengan jenis DM tipe 2 tidak bergantung pada obat insulin karena insulin diproduksi dalam jumlah yang cukup. Oleh sebab tertentu, glukosa gagal masuk ke dalam sel. Kegagalan tersebut disebabkan sel kebal (resisten) terhadap insulin sebagai akibat dari malfungsi dalam penggunaan insulin (Smeltzer \& Bare, 2008).

Hiperglikemi pada penderita diabetes melitus yang tidak terkontol dan terjadi dalam waktu yang lama dapat menyebabkan defisit neurologik yang berat yang sebelumnya ditandai dengan iskemik dan hipoksia otak (WHO, 2012). Keadaan hiperglikemia yang berkelanjutan tersebut, dapat menimbulkan komplikasi diabetes.

Data jumlah penderita Diabetes Melitus pada tahun 2011 telah mencapai 366 juta orang. Jika tidak ada tindakan yang dilakukan, maka jumlah penderita diperkirakan akan meningkat menjadi 552 juta pada tahun 2030 (IDF, 2011). Menurut Riset Kesehatan Dasar Tahun 2013 prevalensi pasien diabetes diperkirakan pada tahun 2015 sebanyak 9,3\%. Sekitar 87-91\% dari semua kasus diabetes yang ada di dunia adalah diabetes tipe 2, 7-12\% diabetes tipe 1, dan 1-3\% adalah diabetes lain, sedangkan di Indonesia, diabetes menempati urutan keempat dengan presentase $2,1 \%$. Peningkatan penderita diabetes mellitus tersebut disebabkan oleh beberapa faktor-faktor yang dapat menyebabkan diabetes mellitus yaitu faktor keturunan, obesitas, sering mengkonsumsi makanan instan, kelainan hormon, hipertensi, merokok, stress, terlalu banyak mengkonsumsi karbohidrat, dan, kerusakan sel pankreas.

Peningkatan jumlah penderita DM akan berdampak pada kondisi fisik dan juga berdampak pada psikologis. Dampak fisik yaitu retinopati diabetik, nefropati diabetic, dan neuropati diabetic. Sedangkan dampak psikologis yang terjadi yaitu kecemasan, kemarahan, berduka, malu, rasa bersalah, hilang harapan, depresi, kesepian, tidak berdaya (Smeltzer \& Bare, 2008). 
PROFESI (Profesional Islam): Media Publikasi Penelitian 2019; Volume 16; No 2.

Website: ejournal.stikespku.ac.id

Penanganan pasien yang dilakukan tenaga kesehatan, selama ini mayoritas berfokus pada pengobatan konvensional yang telah diprogramkan oleh dokter, belum memperhatikan penanganan stress penderita diabetes mellitus sedangkan faktor psikologis sangat berpengaruh terhadap kondisi kesehatan penderita. Apabila stres yang dialami penderita diabetes mellitus dibiarkan saja, dengan kadar gula darah tetap tinggi dan tidak dikelola dengan baik, maka dikhawatirkan komplikasi akut (ketoasidosis diabetes/KAD, asidosis laktat, koma hiperosmolar hiperglikemik non ketotik) sampai komplikasi kronik (retinopati, nefropati, jantung koroner) dapat terjadi (Wade \& Tavns, 2007). Oleh karena itu, diperlukan penanganan secara holistik pada penderita diabetes mellitus.

Diabetes Melitus merupakan penyakit yang dapat dicegah dengan modifikasi gaya hidup yaitu latihan fisik, mengurangi konsumsi lemak dan menurunkan berat badan (Suiraoka, 2012). Penelitian dengan senam diabetes dengan gerakan senam yang penekanannya pada gerakan ritmik otot, sendi, vaskular dan saraf dalam bentuk peregangan dan relaksasi dapat menurunkan gula darah (Rashidlamir dkk, 2012).

Seseorang dengan penyakit kronis atau penyakit serius dapat mengalami kondisi yang stress yang akan memicu pengeluaran beberapa hormon yang berkontribusi dalam meningkatkan kadar gula darah, yaitu glucagon, epinefrin, growth hormone dan glukokortikoid. Pasien stress dapat mengubah kebiasaannya yang baik terutama makan, latihan dan pengobatan (Smeltzer and Bare, 2008). Salah satu tindakan yang dapat dilakukan pada penderita stress kronis adalah dengan terapi komplementer. Terapi ini bersifat pengobatan alami untuk menangani penyebab penyakit dan memacu tubuh sendiri untuk menyembuhkan penyakitnya. Terapi komplemeter antara lain terapi herbal, latihan nafas, meditasi dan relaksasi (Xu Yu, 2004).

Relaksasi merupakan suatu upaya meredakan ketegangan emosional sehingga individu dapat berpikir lebih rasional. Dengan demikian produksi gula hati dapat terkontrol dengan baik, dengan begitu gula darah dapat stabil normal.
Salah satu bentuk cara meredakan ketegangan emosional yang cukup mudah dilakukan adalah relaksasi otot progresif (Suyamto, dkk, 2009). Teknik ini memaksa individu untuk berkonsentrasi pada ketegangan ototnya dan kemudian melatihnya untuk relaks. Orang yang stres, secara emosional tegang dan mengalami ketegangan otot. Teknik ini berusaha meredakan ketegangan otot dengan harapan bahwa ketegangan emosionalpun berkurang, maka dari itu teknik relaksasi otot progresif ini dapat digunakan untuk mendampingi teknik konvensional yang biasa diberikan.

Terapi relaksasi otot progresif yang merupakan salah satu bentuk mind-body therapy (terapi pikiran dan otot tubuh) dalam terapi komplementer (Moyad, 2009). Dalam relaksasi otot individu akan diberikan kesempatan untuk mempelajari bagaimana cara menegangkan sekelompok otot tertentu kemudian melepaskan ketegangan itu (Widyawati \& Yulianti, 2004).

Penelitian sebelumnya tentang relaksasi otot progresif, telah menunjukkan manfaat dalam mengatasi berbagai masalah kesehatan terutama mengurangi ansietas atau kecemasan, dan berkurangnya kecemasan ini mempengaruhi berbagai gejala psikologis dan kondisi medis.

Hasil penelitian Rokhman dkk Tahun 2018 menyatakan terdapat pengaruh terapi progressive muscle relaxation terhadap kecemasan dan kualitas hidup pada pasien DM tipe 2. Terapi progressive muscle relaxation merupakan salah satu teknik manajemen stress dan kecemasan. Terapi tersebut dalam pelaksanaannya mengkombinasikan relaksasi pikiran dan juga melibatkan ketegangan dan relaksasi dari berbagai macam otot tubuh. Sehingga selain bisa untuk menurunkan kecemasan secara kognitif juga mampu mengurangi dampak kecemasan secara fisiologis.

Penelitian Safitri,W dan Agustin, WR (2015) menunjukkan pengaruh terapi relaksasi progresif terhadap penurunan tingkat insomnia pada lansia di Panti Wreda Dharma Bakti Kasih Surakarta. Terapi relaksasi dapat menghambat sekresi norepineprin menyebabkan frekuensi jantung, pernafasan dan glukosa darah menurun (Smeltzer $\&$ Bare, 2008). 
PROFESI (Profesional Islam): Media Publikasi Penelitian

2019; Volume 16; No 2.

Website: ejournal.stikespku.ac.id

Penelitian yang dilakukan oleh Hidayati menyatakan ada pengaruh progressive muscle relaxation terhadap gula darah pada pasien diabetes mellitus tipe 2 di Panti Sosial Tresna Werda Sabai Nan Aluih Sicincin Tahun 2016. Pelaksanaan latihan progressive muscle relaxation selama 5 hari dengan frekuensi latihan dua kali dalam sehari pagi dan sore dengan durasi masing-masing \pm 5 menit dengan 3 kali pengulangan. Pelaksanaan progressive muscle relaxation menyebabkan seseorang akan lebih mudah untuk memusatkan pikiran dan kondisi rileks akan lebih cepat tercapai. Pada keadaan rileks maka otak akan mendapat suplay oksigen yang optimal. Oksigen yang memenuhi seluruh area otak akan beredar seiring dengan denyut jantung untuk didistribusikan ke seluruh organ tubuh. Kondisi ini akan membantu tercapainya kestabilan kerja kelenjar adrenal untuk memproduksi hormon penenang yang akan berdampak pada penurunan stres. Hal ini bertolak belakang dengan dampak stres itu sendiri dimana pada kondisi stres maka gula dalam darah pasien DM akan meningkat. Jika kondisi stres dapat dikendalikan maka gula darah juga akan menurun.

Perbedaan penelitian yang dilakukan penulis dengan penelitian sebelumnya adalah penulis memberikan latihan progressive muscle relaxation dilakukan selama 15-20 menit sebanyak 2 kali sehari selama satu minggu.

Relaksasi otot progresif dapat dilakukan oleh semua orang dalam berbagai kondisi (Setyohadi dan Kushariyadi, 2011). Relaksasi diketahui dapat membantu menurunkan kadar glukosa darah pada pasien diabetes mellitus karena dapat menekan pengeluaran hormonhormon yang dapat meningkatkan kadar glukosa darah, yaitu epinefrin, kortisol, glukagon, adrenocorticotropic hormone (ACTH), kortikosteroid, dan tiroid. Sistem simpatis akan mendominasi pada keadaan seseorang yang rileks dan tenang, dominasi dari sistem saraf simpatis akan merangsang hipotalamus untuk menurunkan sekresi Corticotropin- Releasing Hormon (CRH). Penurunan $\mathrm{CRH}$ juga akan mempengaruhi adenohipofisis untuk mengurangi sekresi hormon Adenokortikotropik (ACTH), yang dibawa mela- lui aliran darah ke korteks adrenal. Keadaan tersebut dapat menginhibisi korteks adrenal untuk melepaskan hormon kortisol. Penurunan hormon kortisol akan menghambat proses glukoneogenesis dan meningkatkan pemakaian glukosa oleh sel (Sherwood, 2014).

Hasil studi pendahuluan yang dilakukan peneliti di RSUD Banyudono Boyolali Bulan Januari 2016 hanya menggunakan teknik konvensional dalam menangani pasien DM tipe 2 pada pasien rawat inapnya yaitu insulin dan obat oral, belum melakukan penatalaksanaan nonfarmakologi lain.

Tujuan dalam penelitian ini untuk menganalisis pengaruh terapi relaksasi progresif terhadap kadar gula darah pasien diabetes mellitus tipe 2 .

\section{METODE PENELITIAN}

Penelitian ini merupakan penelitian quasi eksperimental. Rancangan penelitian yang digunakan adalah one-group pretest-posttest design. Rancangan ini menggunakan satu kelompok sampel yang diukur kadar gula darah puasa sebanyak dua kali, yaitu sebelum diberikan terapi relaksasi progresif (pretest) dan sesudah diberikan terapi relaksasi progresif (posttest).

Populasi dalam penelitian ini adalah penderita DM di RSUD Banyudono. Teknik sampling yang dalam penelitian ini dengan menggunakan purposive sampling. Sampel dalam penelitian ini adalah 18 orang yang telah menandatangani lembar persetujuan menjadi responden penelitian (informed consent).

Kriteria inklusi dalam penelitian ini:

a. Pasien DM tipe 2 dengan kadar gula darah lebih dari normal atau lebih dari $145 \mathrm{mg} / \mathrm{dl}$

b. Pasien DM tanpa komplikasi

c. Bersedia menjadi responden

Kriteria eksklusi dalam penelitian ini adalah:

a. Pasien DM tipe 2 yang yang tidak dapat mengikuti kegiatan secara penuh

b. Pasien DM tipe 2 dengan komplikasi antara lain jantung, stroke dan hipertensi berat.

Alat yang digunakan dalam penelitian ini adalah lembar observasi kadar gula darah puasa, kadar gula darah diukur dengan glukometer yang 
PROFESI (Profesional Islam): Media Publikasi Penelitian 2019; Volume 16; No 2. Website: ejournal.stikespku.ac.id

sudah terkalibrasi. Latihan otot progresif dilakukan selama 15-20 menit sebanyak 2 kali sehari selama satu minggu. Observasi kadar gula darah puasa dilakukan sebanyak 2 kali yaitu sebelum dilakukan latihan relaksasi otot progresif dan setelah latihan relaksasi otot progresif dilakukan selama 1 minggu.

Variabel independen dalam penelitian ini adalah relaksasi otot progresif. Relaksasi otot progresif adalah suatu teknik relaksasi pada otototot besar secara bertahap yang diarahkan untuk membedakan perasaan yang dialami saat kelompok otot dilemaskan dan dibandingkan ketika otot-otot dalam kondisi tegang sehingga dapat membantu seseorang menjadi rileks.

Variabel dependen dalam penelitian ini adalah gula darah. Gula darah adalah Jumlah kandungan glukosa dalam darah yang diukur dengan alat glukometer. Pengolahan data dilakukan dengan menggunakan komputer dengan editing, coding, tabulating dan entry data.

Sebelum dilakukan analisis statistik, terlebih dahulu data hasil penelitian dilakukan uji normalitas untuk melihat distribusi data. Dalam penelitian ini uji normalitas yang digunakan Saphirowilk dan data berdistribusi normal, analisa data dengan uji Paired Simple t test.

\section{HASIL DAN PEMBAHASAN}

Kadar gula darah puasa penderita diabetes mellitus tipe 2 sebelum dilakukan terapi relaksasi progresif

Tabel 1. Deskripsi Kadar Gula Darah Puasa Penderita Diabetes Mellitus Tipe 2 Sebelum Dilakukan Terapi Relaksasi Progresif

\begin{tabular}{ccccc}
\hline KGD & Mean & SD & $\begin{array}{c}\text { Min. } \\
(\mathrm{gr} / \mathrm{dl})\end{array}$ & $\begin{array}{c}\text { Max } \\
(\mathrm{gr} / \mathrm{dl})\end{array}$ \\
\hline Sebelum & 173,07 & 38,60 & 99 & 255 \\
Sesudah & 161,68 & 39,60 & 86 & 230 \\
\hline
\end{tabular}

Tabel 1. menunjukkan rata-rata nilai kadar gula darah pada pre test sebesar $173,07 \mathrm{mg} / \mathrm{dL}$, nilai standar deviasi sebesar 38,60 dengan nilai kadar gula darah terendah sebelum diberikan terapi relaksasi progresif sebesar $99 \mathrm{mg} / \mathrm{dL}$ dan nilai kadar gula darah tertinggi sebesar 255 $\mathrm{mg} / \mathrm{dL}$.

Pasien DM dengan stres, akan terjadi peningkatan hormon-hormon yang mengarah pada peningkatan KGD seperti epineprin, kortisol, glukagon, ACTH, kortikosteroid, dan tiroid akan meningkat (Smeltzer \& Bare, 2008). Respon stres merupakan bagian dari jalur umpan balik yang tertutup antara otot-otot dan pikiran. Penilaian terhadap stressor mengakibatkan ketegangan otot yang mengirimkan stimulus ke otak dan membuat jalur umpan balik (Snyder \& Lindquist, 2002).

Menurut Barnedh (2006) aktivitas fisik mempunyai hubungan bermakna dengan gangguan ekstremitas dimana aktivitas fisik yang rendah, salah satunya tidak teratur berolahraga berisiko terjadi gangguan gerak. Mekanisme tersebut dapat meningkatkan kadar gula darah pada pasien DM tipe 2.

Hasil penelitian menunjukkan ata-rata nilai kadar gula darah pada post test sebesar 161,68, nilai standar deviasi sebesar 39,60 dengan nilai kadar gula darah diberikan terapi relaksasi progresif sebesar $86 \mathrm{mg} / \mathrm{dL}$ dan nilai kadar gula darah puasa tertinggi sebesar $230 \mathrm{mg} / \mathrm{dL}$.

Hasil penelitian ini sesuai dengan Nakayama et al (2012) mengatakan bahwa kontraksi otot dan exercise dapat menurunkan kadar glukosa darah pada penderita Diabetes Melitus Tipe 2 dengan meningkatkan ambilan glukosa (glucose uptake) pada otot rangka melalui translokasi glucose transporter 4 (GLUT 4) ke permukaan sel. Menurut Ghazavi, et al (2007), bahwa latihan relaksasi yang diberikan kepada pasien DM dapat menurunkan kadar HbA1C.

Tabel 2. Hasil Uji Normalitas

\begin{tabular}{cccc}
\hline KGD & Z & P value & Kesimpulan \\
\hline Pre test & 0,941 & 0,104 & normal \\
Post test & 0,935 & 0,122 & normal \\
\hline
\end{tabular}

Tabel 2 menunjukkan $\mathrm{p}$ value 0,104 dan 0,122 nilainya lebih besar dari 0,05 sehingga data berdistribusi normal. 
PROFESI (Profesional Islam): Media Publikasi Penelitian 2019; Volume 16; No 2.

Website: ejournal.stikespku.ac.id

Tabel 3. Kadar Gula Darah Pre dan Post Test Penderita Diabetes Mellitus Tipe 2

\begin{tabular}{lc}
\multicolumn{1}{c}{ Kadar Gula Darah } & p-value \\
\hline $\begin{array}{l}\text { Kadar gula darah pre test } \\
\text { dengan Kadar gula darah post } \\
\text { test }\end{array}$ & 0.001 \\
\hline
\end{tabular}

Tabel 3 menunjukkan $p$-value $=0,001$ $<0,05$, hal ini menunjukkan Ho ditolak, sehingga dapat disimpulkan bahwa ada perbedaan rata-rata kadar gula darah pre test dan post test penderita diabetes mellitus tipe 2 .

Penelitian ini didukung dengan pernyataan Dunning (2003) bahwa terapi komplementer memberikan manfaat pada pasien diabetes yaitu meningkatkan penerimaan kondisi saat ini, menurunkan stres, kecemasan, dan depresi, mengembangkan strategi untuk mencegah stres berkelanjutan, meningkatkan keterlibatan pasien dalam proses penyembuhan diabetes mellitus. Keuntungan terapi. Hasil penelitian Yildirim \& Fadiloglu (2006) menyatakan bahwa relaksasi otot progresif menurunkan kecemasan dan meningkatkan kualitas hidup pasien yang menjalani dialisis.

Teknik relaksasi otot progresif mengaktifkan sitem saraf parasimpatis dan menghentikan kerja saraf simpatis sehingga hormon kortisol menurun yang pada akhirnya glukosa darah menurun. Penelitian Pawlow (2005) menyatakan relaksasi otot berpengaruh terhadap kadar salivary cortisol dan bila dilakukan teratur akan menurunkan risiko komplikasi diabetes mellitus. Penelitian oleh Maghfirah (2015) menunjukkan ada pengaruh relaksasi otot progresif terhadap stress psikologis pasien diabetes tipe 2 .

\section{SIMPULAN}

Hasil penelitian yang telah dilakukan dapat disimpulkan terdapat pengaruh terapi relaksasi progresif terhadap kadar gula darah pasien Diabetes Mellitus. Saran dalam penelitian ini adalah perawat Rumah Sakit dapat memberikan intervensi keperawatan mandiri untuk membantu menurunkan kadar glukosa darah pasien DM dengan terapi relaksasi progresif dan penelitian selanjutnya dapat meneliti variabel lain yang dapat mempengaruhi kadar gula darah.

\section{REFERENSI}

Beever, S. (2006). New Type 2 Diabetes Cases Have Doubled in 30 Years: Health Reporter, http:////www.medicinet.com

Bustan, M. N. (2007). Epidemiologi Penyakit Tidak Menular. Jakarta: Rineka Cipta.

Dunning, T. (2003). Care of people with diabetes: a manual nursing practice. Melbourne: Blackwell Publishing.

Ghazavi, Z., Talakoob, S., Abdeyazdan, Z., Attari, A., dan Joazi, M. (2007). Effects of Massage Therapy and Muscle Relaxation on Glycosylated Hemoglobin in Diabetic Children. April 20, 2010http://semj.sums.ac.ir/vol9/jan2008 /dm.htm

Hasaini, A. (2015). Efektifitas progressive muscles relaxation (PMR) terhadap kadar gula darah pada kelompok penderita diabetes mellitus Tipe II di Puskesmas Martapura. Caring Vol. 2, No. 1, 16-27.

International Diabetes Federation. (2011). One Adult In Ten Will Have Diabetes By 2030. [http://www.idf.org/mediaevents/ press releases/2011/diabetes-atlas-8thedition] [Diunduh pada 10 Desember 2015 pukul $16.45 \mathrm{WIB}]$

Lingga, Lanny. (2012). Bebas diabetes tipe- 2 tanpa obat. Jakarta: Agro Media Pustaka.

Maghfirah, S., Sudiana, IK., Widyawati, Ika Y. (2015). Pengaruh Terapi Relaksasi Otot Progresif Terhadap Status Psikologis dan Perilaku Perawatan Diri Pasien DM tipe 2. Jurnal kesehatan masyarakat. 10 (2): $137-146$

Moyad, M., dan Hawks, J. H. (2009). Complementary and alternative therapies, dalam Black, J. M., \& Hawks. Medical Surgical Nursing; Clinical Management For Positive Outcomes. (8th ed). USA: Elsevier Saunders. 
PROFESI (Profesional Islam): Media Publikasi Penelitian 2019; Volume 16; No 2.

Website: ejournal.stikespku.ac.id

Nakayama K, Tanabe Y, Obara K, Ishikawa T. (2012). Mechanosensitivity of Pancreatic Beta Cells, Adipocytes and Skeletal Muscle Cells: The Therapuetic Targets of Metabolic Syndrome. In A. Kamkin \& I. Lozinsky, eds. Mechanically Gated Channels and Their Regulation. 6th ed. Dordrecht: Springer Sciences + Business Media, pp. 394

Pawlow, L.A \& Jones, G.E. (2005). The impact of abbreviated progressive muscle relaxation on salivary cortisol and salivary immunoglobulin A. Applied Psycho-physiology and biofeedback. 30(4): 375-387

Perkeni (2006). Konsensus Pengelolaan dan Pencegahan Diabetes Mellitus Tipe 2 di Indonesia. Jakarta: PB. PERKENI.

Rashidlamir, A., dkk. (2012). The Effect of 4 Weeks Aerobik Training According with the Usage of Anethum Graveolens on Blood Sugar and Lipoproteins Profile of Diabetic Woman. Annals of Biological Research. 3 (9): 4313-4319. dalam http://scholarresearchlibrary.com/ABRvol3-iss9/ABR-2012-3-9-4313-4319.pdf, diakses tanggal 17 November 2015

Hidayati, Ridha. (2018). Pengaruh progressive muscle relaxation terhadap gula darah pada pasien diabetes mellitus tipe 2 di Panti Sosial Tresna Werda Sabai Nan Aluih Sicincin Tahun 2016. Jurnal Menara Ilmu. XII (4). April 2018

Rokhman, Abdul., Ahsan, dan Supriati, Lilik. (2018). Pengaruh terapi progressive muscle relaxation terhadap kecemasan dan kualitas hidup pada pasien diabetes mellitus tipe 2 di RS Muhammadiyah Lamongan. JRKN 2 (1). April 2018

Setyoadi dan Kushariyadi. (2011). Terapi Modalitas Keperawatan Pada Klien Psikogeriatrik. Jakarta: Salemba Medika.

Sherwood, L. (2014). Fisiologi Manusia: Dari Sel Ke Sistem Edisi 8. Jakarta: EGC.
Soegondo. (2011). Hidup secara mandiri dengan Diabetes Melitus, Kencing Manis, Sakit Gula. Jakarta: FKUI.

Smeltzer, S., Bare, B., Hinkle, J., Cheever, K. (2008). Brunner and suddarth's text book of medical surgical nursing (11th ed). Philadelphia: Lippincort williams \& wilkins

Sudoyo, A.W., Setiyohadi, B., Alwi, I., Simadibrata, M.K. \& Setiati, S. (2009). Buku Ajar Ilmu Penyakit Dalam, jilid III, edisi V. Jakarta: Interna Publishing

WHO (2012). World Health Organization (WHO) Diabetes. Diakses 9 Februari 2016 dari http://www.who.int/entity/diabetes.

Safitri, Wahyuningsih dan Agustin, Wahyu Rima. (2015). pengaruh terapi relaksasi progresif terhadap penurunan tingkat insomnia pada lansia di Panti Wreda Dharma Bakti Kasih Surakarta. Jurnal KesMasDasKa. 6 (1): 54-60

Snyder, M. dan Lindquist, R. (2002). Complementary/ alternative therapies in Nursing.(4thed). New York: Springer Publishing Company.

Suiraoko. (2012). Penyakit degeneratif mengenal mencegah dan mengurangi faktor resiko 9 penyakit degeneratif. Yogyakarta: Nuha Medika

Suyamto, dkk. (2009). Pengaruh Relaksasi Otot dalam Menurunkan Skor Kecemasan TTMAS Mahasiswa Menjelang Ujian Akhir Program Di Akademi Keperawatan Notokusumo Yogyakarta. Berita Kedokteran Masyarakat

Wade, C. \& Tavns, C. (2007). Psikologi. Edisi 9. Jilid 2. Jakarta: Erlangga

Widyawati, Palupi dan Yulianti, Devi. (2004). Manajemen Stres National Safety Council. Jakarta: EGC 
PROFESI (Profesional Islam): Media Publikasi Penelitian 2019; Volume 16; No 2.

Website: ejournal.stikespku.ac.id

$\mathrm{Xu}$ Yu. (2004). Complementary and Alternative Therapies As Physiology and Modalities Implication For Nursing, Education \& Research. Home health care management practice.1: 1084-8223.
Yildirim, Y.K dan Fadiloglu, T. (2006). The effect of progressive muscle relaxation training on anxity levels and quality of life in dialysis patients, April 20, 2010. EDNA/ERCA Journal. 